\section{A Method for Rapid Generation of Competitive Standard Molecules for RT-PCR Avoiding the Problem of Competitor/Probe Cross-reactions} Ralf Ross, Raymonde Kleinz,
and Angelika B. Reske-Kunz

Clinical Research Unit, Department of Dermatology, Johannes Gutenberg-University, D-55101 Mainz, Germany
The analysis of gene expression is a widespread issue in a growing number of fields such as molecular genetics, immunology, and medical diagnostics. The ideal method for mRNA detection should be fast, inexpensive, sensitive, and reliable. Well-elaborated standard methods such as Northern hybridization, S1-mapping, and RNAse protection are useful and recommended, but only reverse transcription PCR (RT-PCR) gives the highest possible sensitivity required. For many issues it is necessary not only to detect a distinct mRNA but to compare changes in mRNA levels. The use of RT-PCR for such semiquantitative and quantitative approaches resolves problems attributable to the intrinsic property of PCR, that is, the variability in the number of copies of products synthesized during the process. Slight differences in reaction conditions can result in drastic differences in product yield. For many applications it is sufficient to compare mRNA levels for a set of probes relative to each other. Even in this case, some parameters still remain to be standardized, for example, it has been shown that the position of the probe in the heating block might be crucial for the product yield. Therefore, protocols commonly used for this purpose include the addition of equal amounts of competitor DNA fragments to the probes to be coamplified during PCR reaction. ${ }^{(1-3)}$ As the competitor fragments are added in equal amounts they should yield equal amounts of PCR products. If the fragments derived from mRNA and the competitor are distinguishable in size, they can be separated easily by gel electrophoresis and visualized by ethidium bromide staining.

Some requirements should be met for generation of such competitor fragments: (1) It is recommended that competitor fragments, which can be amplified with the same pair of primers to minimize differences in amplification conditions for mRNA-derived and competitor-derived products, be used. ${ }^{(4,5)}(2)$ probe and competitor fragment should differ by $<20 \%$ in product length as the amplification efficiency decreases with product length; and (3) sequence identity between probe and competitor fragment should be minimized. Here, we show that the latter is essential to avoid hybrid formation between competitor fragment and probe, as hybrid formations interfere with the PCR efficiency and with proper quantification of product yield.

In this report we describe a simple PCR-based method to construct competitor fragments that fit all of these requirements. Using this approach, we analyzed the expression of the murine inducible nitric oxide synthase (iNOS) ${ }^{(6,7)}$ in the murine keratinocyte cell line PAM 212.

\section{MATERIALS AND METHODS}

\section{mRNA Extraction and CDNA Synthesis}

The murine epidermal keratinocyte cell line PAM $212^{(8)}$ was maintained in Iscove's modified Dulbecco's medium with $5 \%$ fetal calf serum (FCS) and $1 \mathrm{~mm}$ L-glutamine. Equal cell numbers $\left(1 \times 10^{5}\right.$ to $1 \times 10^{6}$ cells) were stimulated as outlined below and subjected to mRNA preparation using the micro-mRNA purification kit (Pharmacia, Freiburg). RNA concentration and quality were assessed performing RT-PCR with $\beta$-actin-specific primers and subsequent electrophoresis on nondenaturing vertical $1.4 \%$ agarose gels.

Before starting reverse transcription, mRNA in aqueous solution $(3 \mu \mathrm{l})$ was denatured at $65^{\circ} \mathrm{C}$ for $5 \mathrm{~min}$ and chilled on ice. A cDNA synthesis mixture was added to a final volume of $20 \mu \mathrm{l}$ containing 5 $\mathrm{mM} \mathrm{MgCl}_{2}, 50 \mathrm{~mm} \mathrm{KCl}, 10 \mathrm{~mm}$ Tris- $\mathrm{HCl}$ (pH 8.3), $1 \mathrm{~mm}$ dNTP, $2.5 \mu \mathrm{M}$ random hexamer primer, $1 \mathrm{U} / \mu \mathrm{l}$ of RNAse inhibitor, and $2.5 \mathrm{U} / \mu \mathrm{l}$ of murine leukemia virus reverse transcriptase (MuLV-RT). All reagents for CDNA synthesis were purchased from Perkin-Elmer Cetus (Ueberlingen). The reaction was carried out at $40^{\circ} \mathrm{C}$ for $15 \mathrm{~min}$, followed by $5 \mathrm{~min}$ at $95^{\circ} \mathrm{C}$ and $5 \mathrm{~min}$ at $4^{\circ} \mathrm{C}$. The RT reaction mixture was used directly for PCR.

\section{Primers}

Primers were purchased from MWG Biotech (Ebersberg), Primers act1 (5'-GTGGGCCGCTCTAGGCACCA) and act2 (5'TAGCCCTCGTAGATGGGCACAG) were chosen to amplify a 403-bp fragment of murine $\beta$-actin cDNA. The primers iNOS1 (5'-AATAGAGGAACATCTGGCCAGG) and iNOS2 (5'-ATGGCCGACCTGATGTTGC) amplify a 258-bp product of iNOS, and the primers st1 (5'-GGAACATCTGGCCAGGCCGCTCTAGGCACCA) and st2 (5'-CCGACCTGATGTTGCGGGT- 
GTTGAAGGTCT) were used for the construction of a competitor template as outlined below.

\section{PCR Conditions and Quantification}

PCR was performed under mineral oil in a total volume of $100 \mu \mathrm{l}$. The $20 \mu \mathrm{l}$ of RT reaction mixture was brought to $2 \mathrm{mM}$ $\mathrm{MgCl}_{2}, 50 \mathrm{~mm} \mathrm{KCl}, 10 \mathrm{~mm}$ Tris- $\mathrm{HCl}$ (pH 8.3), $0.2 \mathrm{~mm} \mathrm{dNTP}$, and $1.5 \mu \mathrm{M}$ of each required primer. Amplification was carried out in a Perkin-Elmer Cetus 480 Thermal Cycler (Ueberlingen). Taq polymerase (2.5 units) was added to start the reaction when the reaction mixture had reached $94^{\circ} \mathrm{C}$ (hot start). The cDNA was amplified in 33 cycles with 1 min denaturation at $94^{\circ} \mathrm{C}, 1 \mathrm{~min}$ annealing at different temperatures, and $1 \mathrm{~min}$ extension at $72^{\circ} \mathrm{C}$. Following the 33 cycles a final extension was performed for $7 \mathrm{~min}$ at $72^{\circ} \mathrm{C}$. For iNOS- and $\beta$-actin amplification the annealing temperature was decreased during the first 8 cycles $(2 \times$ at $69^{\circ} \mathrm{C}, 2 \times$ at $68^{\circ} \mathrm{C}, 2 \times$ at $67^{\circ} \mathrm{C}, 2 \times$ at $66^{\circ} \mathrm{C}$ ) followed by 25 cycles at $65^{\circ} \mathrm{C}$ (touchdown protocol) to increase the specificity. The amplification with the chimeric primers st 1 and st 2 is described below. The PCR products were analyzed on nondenaturing, vertical $1.4 \%$ agarose gels in $1 \times$ TBE, stained with ethidium bromide, and detected under UV light. Fluorescence of the products was detected relative to each other and to the marker fragments, using an imaging system (Herolab, Wiesloch).

\section{Cloning and Sequencing}

RT-PCR products were subcloned in pUC 18 and transformed in Escherichia coli strain RR1. Recombinant plasmids were selected by colony filter hybridization and sequenced by a standard double-stranded dideoxy method. ${ }^{(9)}$ The BamHI site of the vector was destroyed by cleavage with BamHI, followed by end-filling with Klenow DNA polymerase (Amersham, Braunschweig), and integration of the RT-PCR product, thus, it was possible to linearize the plasmid using a Bam $\mathrm{HI}$ restriction site within the RT-PCR product. BamHI yields 5'-overhanging ends that are substrates for exonuclease III digestion. Internal deletions were carried out using the nested deletion kit (Pharmacia, Freiburg) following the instructions of the manufacturer.

\section{RESULTS}

\section{Primer Selection for RT-PCR and Subcloning of the Amplified Products}

Primers were selected to amplify a 258 bp fragment derived from murine iNOS mRNA. iNOS is one of three isoenzymes catalyzing the reaction L-arginine $\rightarrow 1$ citrulline + nitric oxide. ${ }^{(6)}$ Using these primers a product of the predicted length was amplified from the PAM 212 cell line. Sequencing of individual positive subclones confirmed that the amplified fragments were identical with the published murine iNOS mRNA sequence (data not shown).

\section{Competitor Fragments Obtained by Internal Deletion of the PCR Product Result in Competitor/Probe Cross-hybridization}

To obtain competitor fragments for RTPCR sharing the primer sequences with the cDNA-derived product, we internally deleted the cDNA-derived product by performing the nested deletion procedure described in Materials and Methods. To test this competitor, a reverse transcription reaction mixture [mRNA from $\gamma$-interferon (INF- $\gamma$ )-stimulated PAM 212 cells] was distributed evenly into five samples, mixed with decreasing concentrations of competitive fragments, and subjected to PCR. In addition to the two predicted fragments representing the competitive fragment and the mRNA-derived product, a third fragment was detected that migrated slower than the two other fragments (Fig. 1). The highest number of copies of the third fragment was detected in samples with similar concentrations of competitor fragment and cDNA-derived fragment. Based on this finding we concluded that the third fragment could be a hybrid molecule of a cDNA-derived and a competitor-derived DNA strand. Because of the internal deletion of the competitor fragment, the hybrid molecules should be forming a singlestranded loop, slowing down the migration in agarose gel electrophoresis. To prove this hypothesis we cut out the upper band, recovered and heat-denatured the DNA, and added iNOS primer, dNTP, and Klenow DNA polymerase to synthesize the complementary DNA strands. We obtained two fragments of cDNA and competitor size (data not shown).

\section{PCR-based Construction of Competitor Fragments for RT-PCR with Minimized Sequence Identity with the cDNA-derived Product}

To exclude hybrid formation between cDNA-derived and competitor-derived fragments, we constructed fragments that were amplifiable with iNOS1 and iNOS2 but that lacked any further sequence identity to the iNOS CDNA. Our strategy for the construction is shown in Figure 2. We started with a 403-bp RTPCR product of murine actin CDNA amplfied using the primers act1 and act2. With this well-defined product we performed PCR with the hybrid primers st1

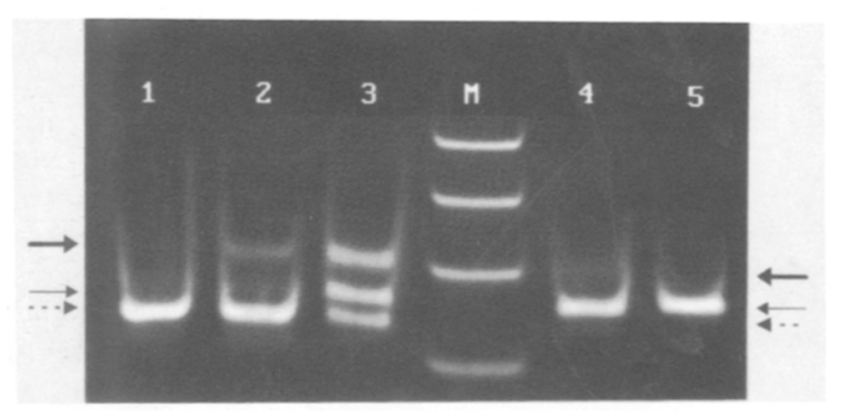

FIGURE 1 Competitive RT-PCR using internally deleted competitor fragments. The concentration of the competitor template added to the reaction (lane 1) (dotted arrows) was decreased 10-fold for each following lane. In addition to the cDNA-derived product (thin arrows) and the competitor-derived product, a third fragment (bold arrows), representing hybrid molecules, is distinguishable in some lanes (e.g., lane 3). (Lane M) Molecular weight marker 100-bp ladder (Pharmacia, Freiburg). 
1.

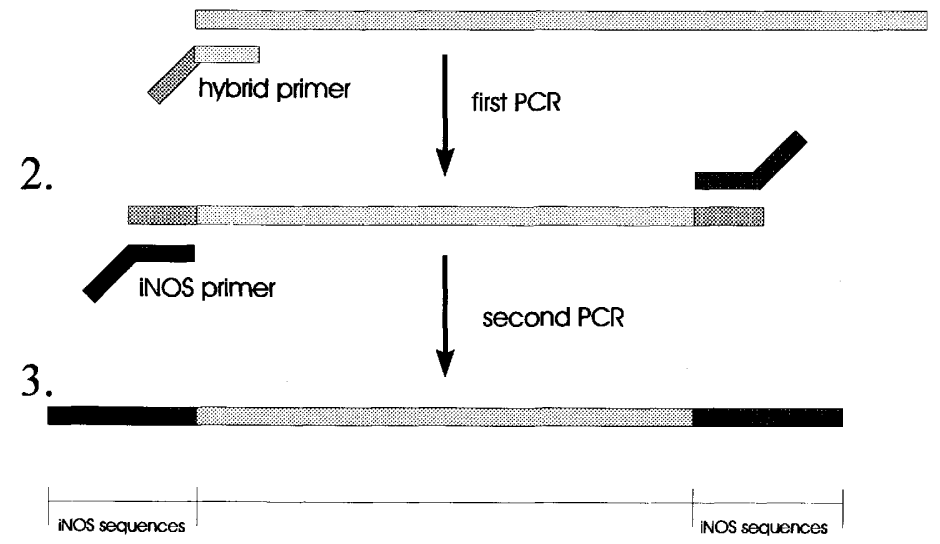

FICURE 2 Strategy for the construction of competitor templates for PCR using hybrid primers. The resulting product is flanked by the primer sequences for the target gene iNOS but comprises no further homology to iNOS in between. For a more detailed description, see text.

and st 2 . The 15 nucleotides at the $3^{\prime}$ end of st 1 and st 2 match the actin product and the 15 nucleotides at the $5^{\prime}$ end of the primers are identical to the $3^{\prime}$ end of iNOS1 and iNOS2. The PCR was carried out at very low stringency (annealing at $42^{\circ} \mathrm{C}$ ) to allow annealing of the short homologous part of st 1 and st 2 to the actin cDNA. As the primer st 2 binds 118 bp within the actin cDNA fragment the amplified product is distinguishable in length from the starting $\mathrm{cDNA}$. The product was diluted 10,000-fold and reamplified with the primers iNOS1 and iNOS2 under low stringency. Because of the 15-bp 5' overhang at both ends of the starting product, the amplified fragment is also distinguishable in length. The resulting product carries the primer sequence of iNOS1 and iNOS2 at the ends and internally exhibits no sequence identity with the iNOS cDNA. The length of the product is dependent solely on the choice of the hybrid primers. This product was diluted and subjected to competitive RT-PCR without further purification.

RT-PCR with serial dilutions of starting cDNA and constant amounts of competitor fragments was performed. No hybrid formation was detected and the concentration of the competitor fragment remained nearly unchanged, whereas the cDNA input was increased up to $10^{6}$ fold (Fig. 3). The slight influence of the competitively amplified cDNA on the product yield of the competitor fragment is tolerable.

Using this assay we show that murine
PAM 212 keratinocytes express iNOS cDNA. The expression is enhanced by lipopolysaccharide (LPS) and INF- $\gamma$ (Fig. 4) as reported for macrophages. ${ }^{(10)}$ The enhancement was calculated for unstimulated, INF- $\gamma$-, LPS-, and LPS + INF- $\gamma$ stimulated cells as $1,5.6,7.8$, and 26.6, respectively, using an imaging system (Herolab, Wiesloch). Differences in product yield of the competitor fragment $(<7.5 \%)$ were taken into account. For densitometrical measurements of the fluorescence intensity of the amplified fragments, serial dilutions of the stimulated probes were performed and (Fig. 4B). Dilutions of nearly equal fluo-

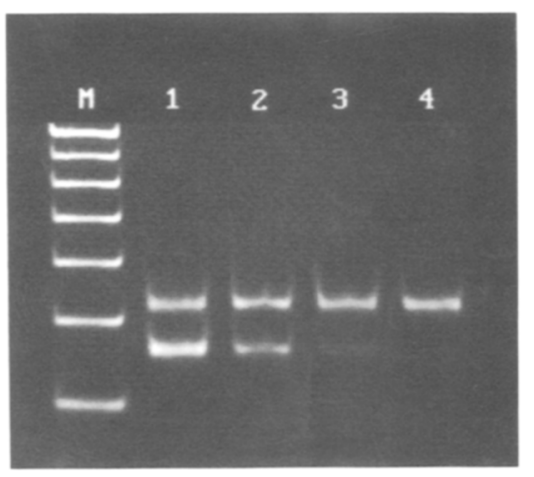

FICURE 3 Competitive iNOS RT-PCR using the competitor template construct. The competitor fragment was added in equal amounts (upper band), whereas the cDNA added to the reaction (lane 1) was diluted 10-fold for each following lane. (Lane $M$ ) Molecular weight marker, 100-bp ladder (Pharmacia, Freiburg). compared with the unstimulated probe rescence intensity were used for calculation of the expression ratio. The results show that iNOS expression is enhanced by LPS and INF- $\gamma$ synergistically. The product yield of the double-stimulated cells surmounts the combined amounts calculated for cells either stimulated with LPS or INF- $\gamma$.

\section{DISCUSSION}

In this report we describe a rapid and reliable method to construct competitor templates for PCR of any given gene. As the starting material for the competitor fragment, any defined PCR product, vector, of cloned fragment without sequence homology to the gene in question would be suitable. The length of the competitor fragment can arbitrarily be chosen by selection of the proper distance between the hybrid primers on the starting DNA. The only additional requirements for the construction of the competitor fragment are the two hybrid primers. The success of each step of the procedure can be monitored easily by gel electrophoresis. Purification of the generated competitor fragment is not necessary as the primers used for RT-PCR will neither match the first template nor the chimeric primers under higher stringency. As the competitor product can be diluted $10^{4}-10^{8}$-fold for RT-PCR, contaminations with primers, used for the construction of the competitor template, can be ignored. This method can be used for the generation of competitor fragments detectable by most of the common methods including detection of length differences by gel electrophoresis, ${ }^{(11)}$ restriction with competitor-specific endonucleases, ${ }^{(12)}$ and hybridization with competitor- or probe-specific oligonucleotides. ${ }^{(11)}$ If subcloned into an appropriate expression vector, RNA competitor fragments can be generated easily by this process. Added in equal amounts to cell lysates, such a RNA competitor template will be copurified and amplified. It is therefore possible to estimate the original number of copies of mRNA molecules of the cell lysate.

The necessity to minimize sequence homology between competitor fragment and cDNA must be stressed, especially as the use of cDNA-derived competitor templates, constructed by internal deletion or integration of extra DNA, is widespread. ${ }^{(1,2,5,13)}$ For quantitative analysis it is necessary to optimize the PCR con- 

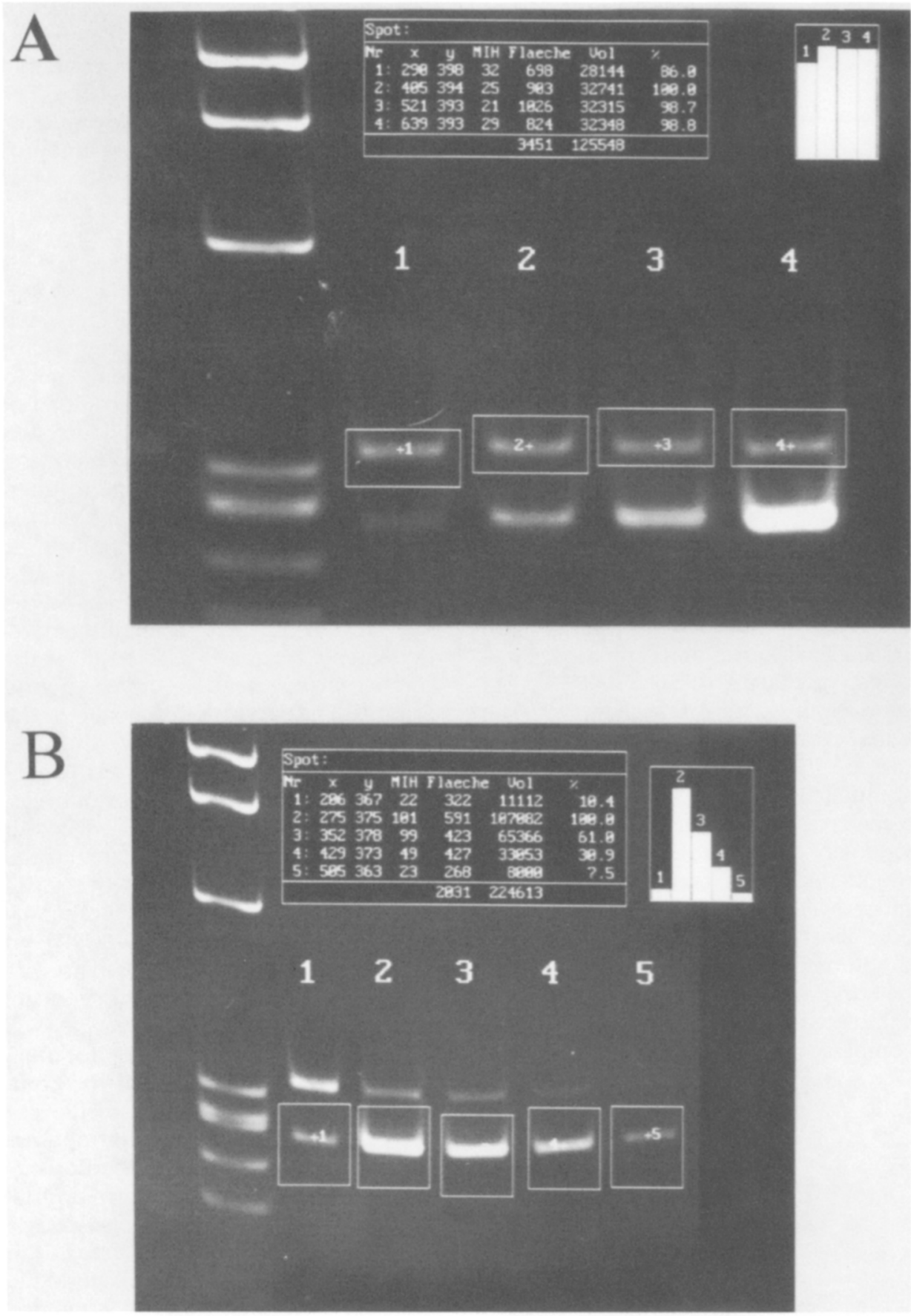

FIGURE 4 Competitive iNOS RT-PCR employing PAM 212 cells. $(A)$ Equal amounts of cells were used unstimulated (lane 1) or stimulated with $100 \mu \mathrm{g} / \mathrm{ml}$ of LPS (lane 2), $10 \mathrm{U} / \mathrm{ml} \mathrm{of} \mathrm{INF- \gamma} \mathrm{(lane}$ 3 ), and LPS + INF- $\gamma$ (lane 4). Molecular weight marker $\phi X 174 /$ HaellI (Pharmacia, Freiburg). The insert depicts the densitometrical measurement (imaging system; Herolab, Wiesloch) of the fluorescence intensity of the competitor fragments. $(B)$ Unstimulated probe (lane 1$)$ compared with serial dilutions of the LPS/NF- $\gamma$-stimulated probe (lanes 2-5). For a more detailed description, see text.

ditions to ensure that every PCR cycle works with comparable amplification efficiency. The latter is especially not true in the late phase of PCR because amplification efficiency decreases. Many parameters contribute to this plateau effect, but a major problem is rehybridization of the amplified fragments. ${ }^{(14)}$ The higher the concentration of the fragments, the more likely it is that frag- ments will rehybridize following denaturation rather than anneal with a primer for subsequent amplification. Using competitor fragments that do not cross-hybridize with the cDNA-derived products drastically reduces the actual concentration of DNA fragments that can hybridize with each other, thus extending the range of amplification steps to be used. This is especially important for direct comparison of very different mRNA levels (see Fig. 4A). Furthermore, even under optimal PCR conditions rehybridization of fragments will occur; therefore, every precaution should be taken to reduce the level of rehybridization. In addition, many quantitative methods detect double-stranded DNA. ${ }^{(11,12)}$ This leads to miscalculations attributable to hybrid formation.

The method described here is applicable for clinical use and other fields because of its reliability and precision. In addition, it is nonradioactive, easy to handle, and does not require the use of recombinant gene technology.

\section{ACKNOWLEDGMENTS}

This work was supported by the Deutsche Forschungsgemeinschaft Kn 120/6-1.

\section{REFERENCES}

1. Gilliland, G., S. Perrin, and H.F. Bunn. 1990. Competitive PCR for quantitation of mRNA. In PCR protocols: A guide to methods and applications (ed. M.A. Innis, D.H. Gelfand, J.J. Sninsky, and T.J. White), pp. 60-69. Academic Press, San Diego, CA.

2. Gilliland, G., S. Perrin, K. Blanchard, and H.F. Bunn. 1990. Analysis of cytokine mRNA and DNA: Detection and quantitation by competitive polymerase chain reaction. Proc. Natl. Acad. Sci. 87: 27252729.

3. Ferre, F. 1992. Quantitative or semi-quantitative PCR: Reality versus myth. PCR Methods Applic. 2: 1-9.

4. Lundeberg, J., J. Wahlberg, and M. Uhlen. 1991. Rapid colorimetric quantification of PCR-amplified DNA. BioTechniques 10: 68-75.

5. Wang, A.M., M.V. Doyle, and D.F. Mark. 1989. Quantitation of mRNA by the polymerase chain reaction. Proc. Natl. Acad. Sci. 86: 9719-9721.

6. Morris, S.M., Jr. and T.R. Billiar. 1994. New insights into the regulation of inducible nitric oxide synthesis. Am. J. Physiol. 266: E829-E839.

7. Nathan, C. and Q.-W. Xie. 1994. Nitric ox- 
ide synthases: Roles, tolls, and controls. Cell 78: 915-918.

8. Ympa, S.H., P. Hawley-Nelson, B. Koehler, and J.R. Stanley. 1980. A survey of transformation markers in differentiating epidermal cell lines in culture. Cancer Res. 40: 4694-4703.

9. Chen, E.Y. and P.H. Seeburg. 1984. Supercoil sequencing, a fast and simple method for sequencing plasmid DNA. DNA 4: 165-170.

10. Nathan, C. and Q.-W. Xie. 1994. Regulation of biosynthesis of nitric oxide. J. Biol. Chem. 269: 13725-13728.

11. Jenkins, F.J. 1994. Basic methods for the detection of PCR products. PCR Methods Applic. 3: 577-582.

12. Harlow, S.P. and C.C. Stewart. 1993. Quantitation of c-myc gene amplification by a competitive PCR assay system. PCR Methods Applic. 3: 163-168.

13. Platzer, C., G. Richter, K. Überla, W. Müller, H. Blöcker, T. Diamantstein, and T. Blankenstein. 1992. Analysis of cytokine mRNA levels in interleukin-4-transgenic mice by quantitative polymerase chain reaction. Eur. J. Immunol. 22: 11791184.

14. Jensen, M.A. and N. Straus. 1993. Effect of PCR conditions on the formation of heteroduplex and single-stranded DNA products in the amplification of bacterial ribosomal DNA spacer regions. PCR Methods Applic. 3: 186-194.

Received December 27, 1994; accepted in revised form March 15, 1995. 


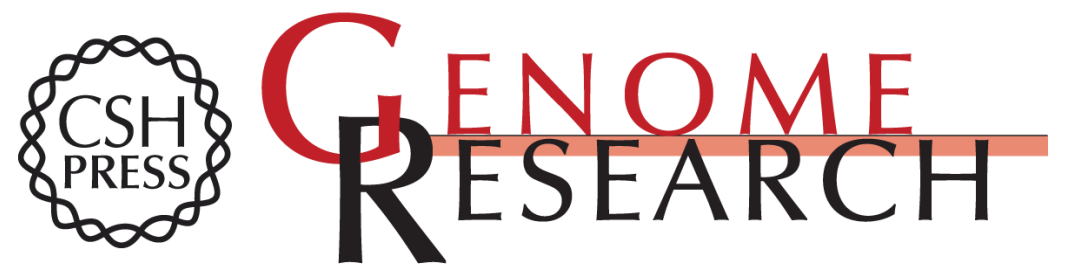

\section{A method for rapid generation of competitive standard molecules for RT-PCR avoiding the problem of competitor/probe cross-reactions.}

R Ross, R Kleiz and A B Reske-Kunz

Genome Res. 1995 4: 371-375

References

This article cites 13 articles, 3 of which can be accessed free at: http://genome.cshlp.org/content/4/6/371.full.html\#ref-list-1

\section{License}

Email Alerting Service

Receive free email alerts when new articles cite this article - sign up in the box at the top right corner of the article or click here.

\section{Affordable, Accurate Sequencing.}

